\title{
The Russian Understanding of War: Blurring the Lines between War and Peace
}

\author{
Oscar Jonsson \\ Washington DC: Georgetown University Press 2019 \\ 187 sider. ISBN 9781626167346
}
Omtalt av Julie Wilhelmsen [ph.d., seniorforsker ved Norsk utenrikspolitisk insti- tutt (NUPI), jw@nupi.no]

For de av oss som følger diskusjonen om Russland i verdenspolitikken tett, er det noen ofte gjentatte utsagn som etter hvert utløser en slags matthet eller kynisme. At Russland har kodifisert og fører en «hybrid krig» mot Vesten, er et av disse. Problemet med utsagnet er ikke at Russland ikke ser seg som i konflikt med Vesten og opptrer deretter. Det gjør Russland. Problemet er at dette begrepet hverken er sentralt eller nytt for russiske militære tenkere rent faktisk. Videre gir den gjentatte påstanden om at hybrid krigføring er en russisk praksis oss inntrykk av at Russlands ledere helt på egen hånd har klekket ut en ny, skummel form for krig. I denne situasjonen er Oscar Jonssons bok The Russian Understanding of War: Blurring the Lines between War and Peace et sårt tiltrengt, nitid dokumentert og ypperlig bidrag til forskning og opplysning.

Boka har en innledning som setter bokens sentrale tema, Russlands forståelse av krig, i kontekst. Dette grepet er viktig, og skiller Jonssons bok fra mange av de populære analysene om dette tema. Deretter følger to kapitler som legger frem og dokumenterer utviklingen av denne forståelsen før og etter Sovjetunionens fall, i kronologisk rekkefølge. De to siste kapitlene konsentrerer seg om «informasjonskrigføring» og «fargerevolusjoner», som har vært de formative begrepene i den idémessige endringen i Russlands forståelse av krig.

Gjennom hele boka trekkes det på tekster fra sentrale militærteoretikere, russiske beslutningstagere og offisielle doktriner. Jonsson presenterer ikke gjetninger om russiske intensjoner, men tar heller russiske utsagn som en refleksjon av hvordan de faktisk leser verden, og som en veileder til å forstå russisk sikkerhetspolitisk handling. Boka kan kritiseres for å være repetitiv og doktorgradspreget. Fordelen er at balansen, grundigheten og påliteligheten er upåklagelig. 
Jonsson begynner med å slå fast at Vestens feilaktige lesning av Russlands forståelse av krig kan være konflikteskalerende i seg selv, i hvert fall kombinert med Russlands egen lesning av Vestens maktbruk siden den kalde krigens slutt. Han giennomgår foreliggende vestlig litteratur på feltet, og hevder begreper som «hybrid krigføring» og "Gerasimov-doktrinen» har blitt tillagt vekt feilaktig. I stedet tilbyr han en genealogi av «krigens natur» basert på russiske tekster, og understreker hvordan denne forståelsen har utviklet seg gradvis.

Endringen i russisk tenkning innebærer et skifte bort fra å definere krigens natur i tråd med Clausewitz' klassiske vektlegging av krig som bruk av veepnet makt for å oppnå politiske mål, til å innbefatte ikke-militære, «myke» våpen. I dagens russiske bilde er bruk av for eksempel ny informasjons- og kommunikasjonsteknologi for å påvirke massenes bevissthet og verdier blitt sofistikerte og utbredte våpen. De er "voldelige», eroderer motstanderstatens makt innenfra, og er langt mer effektive enn væpnet makt. Slik har skillet mellom krig og fred blitt visket ut, og det er blitt hensiktsmessig for dagens deltagere i stormaktspolitikken å uttømme den myke maktens potensial før man tar i bruk militærmakten.

Likevel, ifølge russisk offisiell doktrine utgjør væpnet makt fremdeles kjernen i krigens natur. Er det noe Jonssons studie viser, så er det hvor stor kontinuitet og refleksivitet det er i den russiske debatten. Spirene til dagens tenkning er å finne i før-revolusjonære og sovjetiske debatter. Endringene drives frem gjennom interne diskusjoner og enda mer, i flukt med russernes observasjoner av amerikansk og vestlig «krigføring».

Dette begynner allerede under Gulfkrigen på tidlig 1990-tall da USA utøver det som kalles 6. generasjonskrigføring, på lang avstand, med kombinasjonen av informasjonskrig og teknologisk avanserte våpen - for å ødelegge motstanderens økonomiske fundament. I russernes lesning av Kosovokrigen i 1999 vektlegges informasjonsaspektet i moderne krigføring ytterligere. Tesen om at Vestens motstandere primært nedkjempes gjennom ikke-militære, undergravende tiltak vokser med de såkalte fargerevolusjonene i det tidligere post-sovjetiske området fra 2003 og fremover, men var i utgangspunktet knyttet til tolkningen av vestlige NGOers virksomhet i området. Utover 2010-tallet sporer NATOs tilstedeværelse nærmere Russlands grenser kombinert med Vestens angivelige misbruk av humanitær intervensjon og myk makt i forbindelse med «Den arabiske våren» an dreiningen i den russiske forståelsen av krigens natur.

I kjølvannet av demonstrasjonene mot Putin-ledelsen i 2011/2012 og «Euromajdan» i Kiev i 2014 foredles ideen om at spredning av liberal-demokratiske verdier for å utløse protestpotensialet og skape «kontrollert ustabilitet» $\mathrm{i}$ fremmede makters befolkning er vestlige staters farligste våpen. Ifølge noen russiske militærteoretikere består nå moderne krigføring av $80 \%$ informasjonskrig og $20 \%$ militær maktbruk. I motsetning til vestlig militærteori, som er opptatt av de teknologiske aspektene ved informasjonskrig, er de russiske langt mer opptatt av innholdet $\mathrm{i}$ informasjonen. I det som nå forstås som en «sivilisasjonskamp» med Vesten, må Russland skjerme egen 
befolkning fra ytre påvirkning og skape sosial enhet innad gjennom «patriotisk» og «åndelig» fostring, samt kontroll av informasjonssfæren. Nasjonalgarden etableres $i$ 2016 for å bekjempe en kommende russisk fargerevolusion, og som et tydelig tegn på at krigen antas å foregå på hjemmebane. Utad blir militær og ikke-militær avskrekking påkrevet, deriblant «informasjonsavskrekking».

Boken redegiør saklig for den russiske militærtenkningens paranoide trekk, eksemplifisert ved ideen om at Gorbatsjovs forsoningslinje overfor Vesten i sin tid var vestlige makters første vellykkede informasjonsoperasjonen for å ramme Russland. Når dette fortolkningsfilteret rammer inn enhver vestlig (re)aksjon - selv økonomiske sanksjoner eller menneskerettighetskritikk forstås som del av vestlig krigføring - og Russland finner det maktpåliggende å slå tilbake med samme våpen, kan vi få inntrykk av at krigen virkelig er nær.

Når en leser Jonssons fremstilling blir man likevel slått av hvordan den nye russiske forståelsen av krigens natur, som jo former dagens selvhevdende handlingsmønster, er «defensivt» drevet fram - som noe Russland er nødt til å implementere for å beskytte seg selv.Videre er det verdt å bite seg merke i at en del sentrale russiske tenkere, som general Makhmut Gerejev, eksplisitt uttrykker frykt for en utvikling der skillet mellom krig og fred viskes ut, nettopp fordi «alt blir krig» og forholdet mellom statene ødelegges. Derfor vil ikke Russland offisielt forandre definisjonen av krig før det er internasjonal enighet om det. Heri ligger det kanskje en mulig vei tilbake, dersom vestlige stater kunne få øye på den russiske forståelseshorisonten og finne det for godt å sette i verk noen beroligende tiltak?

Alt $\mathrm{i}$ alt er boken er et argument for å studere utviklingen av ideer i russiske uttalelser og tekster snarere enn å avvise slikt materiale som farlig propaganda. Som Jonsson sier, har teori og konsepter praktisk, politisk betydning. Ingenting av det vi så av Russlands handlinger i Ukraina, Syria eller det amerikanske valget i 2016 kom ut av det blå. Den russiske «revansjen» var varslet og lesbar ut fra offentlig tilgjengelige tekster. Jonssons bok bidrar også til å opprettholde den viktige kunnskapsutvekslingen mellom forskning og politikk i en urolig tid. Den formidler et russisk utsyn det er maktpåliggende for vestlige beslutningstagere å ta med i betraktning for fremtidige beslutninger om hvordan man skal motstå Russland, og om hvordan man skal de-eskalere konflikten med Russland. 